DOI:

http://e-journal.stit-islamic-village.ac.id/index.php/JECIES

\title{
URGENSI PENDIDIKAN KARAKTER PADA ANAK USIA DINI DALAM TINJAUAN NEUROSAINS
}

\author{
Aas Siti Sholichah \\ Institut Perguruan Tinggi Ilmu Al-Qur'an \\ Email: shalichah@gmail.com
}

Received: 12 Februari, 2020.

Accepted: 24 Februari, 2020.

Published: 30 Maret, 2020

\begin{abstract}
This article will explain the urgency of early childhood character education in neuroscience review. The methods of research used are qualitative methods with a library approach. Neuroscience is a science that studies and specializes in scientific to the nervous system. In the study of early childhood neuroscience is a golden age in the process of human growth. Brain tissue cell growth in children aged 0-4 year reaches $50 \%$, up to 8 years of age reached $80 \%$. The rapid development of the brain along with the child's physical growth. In early childhood, the unconscious mind is functioning since the womb until age 5 years. The unconscious mind has the function of storing, habits, emotions, long-term memory, intuition, personality, creativity, belief, perception and value. The physical fact of the unconscious mind can be proved when the baby is crying that can be calm in the dethe mother, because since the baby is already acquainted with the figure of his mother through the uterus and heart rate. When viewed from its fugness, the subconscious mind serves to form a character.
\end{abstract}

Keywords: Early childhood, Neuroscience, Character Education.

\section{ABSTRAK}

Tulisan ini akan menjelaskan mengenai urgensi pendidikan karakter anak usia dini dalam tinjauan neurosains. Adapun metode penelitian yang digunakan adalah metode kualitatif dengan pendekatan kepustakaan. Neurosains adalah ilmu yang mempelajari dan mengkhususkan pada saintifik terhadap sistem saraf. Dalam kajian neurosains anak usia dini merupakan masa keemasan dalam proses tumbub kembang manusia. pertumbuban sel jaringan otak pada anak usia 0-4 tabun mencapai 50\%, hingga usia 8 tahun mencapai 80\%. Pesatnya perkembangan otak tersebut bersamaan dengan pertumbuban fisik anak. Dalam tahap anak usia dini, pikiran bawah sadar berfungsi sejak dalam kandungan sampai usia 5 tabun. pikiran bawah sadar memiliki fungsi menyimpan, kebiasaan, emosi, memori jangka panjang, intuisi, kepribadian, kreatifitas, keyakinan, persepsi dan nilai. Fakta secara fisik pikiran bawah sadar ini dapat dibuktikan ketika bayi menangis yang bisa tenang dalam dekapan ibunya, karena semenjak dalam kandungan bayi sudah mengenal sosok ibunya melalui rabim dan detak jantung. Jika dilihat dari fugsinya, pikiran bawah sadar berfungsi untuk membentuk karakter.

Kata Kunci: Anak Usia Dini, Neuroscience, Pendidikan Karakter. 


\section{PENDAHULUAN}

Pendidikan karakter yang diberikan dan distimulus sejak usia dini akan memberikan efek yang positif terhadap tumbuh kembang dan kepribadian. Berdasarkan hasil penelitian yang dilakukan Universitas Otago New Zealand yang kemudian diteliti kembali pada saat usia 18 dan 21 tahun juga usia 26 tahun, memberikan informasi hasil penelitian bahwa, anak usia 3 tahun yang memiliki sehat jiwa (well-adjusted toddlers), setelah dewasa maka karakter terbentuk dan menjadi sehat jiwanya, sedangkan anak usia 3 tahun yang memiliki permasalahan seperti susah diatur, pemarah dan pembangkang (uncontrollable toddlers) pada saat usia 18 tahun menjadi remaja yang memiliki permasalahan dalam pergaulan, dan saat usia 21 tahun menjadi remaja yang sulit untuk membina hubungan baik secara sosial dan terlibat dalam tindakan criminal (Zubaedi, 2017:1).

Berdasarkan hasil penelitian tersebut pentingnya memberikan dan menstimulus pendidikan karakter sejak anak usia dini, karena ketika orang tua dan pendidik mampu memberikan pendidikan karakter yang baik di usia 0-3 tahun pertama maka akan membentuk karakter anak seumur hidup. Setelah usia 3 tahun peran orang tua dalam pendidikan karakter adalah melakukan stimulus dengan cara keteladanan dan pembiasaan.

Pentingnya pendidikan karakter yang diberikan sejak usia dini akan mempengaruhi pola kehidupan masa selanjutnya, pendapat tersebut sejalan dengan piaget yang menjelaskan bahwa terdapat masa keemasan anak (golden ages) yang menjadi masa tertinggi perkembangan anak-anak. Hal ini menjadi penting karena masa-masa tersebut merupakan masa dimana anak dapat diarahkan untuk melakukan hal yang baik sesuai dengan pembiasaan dan karakter orang tua. Piaget menemukan bahwa anak-anak berusia 0-6 tahun mengakui keberadaan aturan, meskipun tidak sepenuhnya konsisten, maka pada awal pekembangan ini piaget menyebutnya dengan moralitas heteronom atau disebut juga tahap realisme moral. Heteronom artinya tunduk pada aturan yang diberlakukan orang lain, sehingga pelanggaran aturan diyakini akan membawa hukuman otomatis (Slavin, 2017: 68-69).

Pandangan tersebut beririsan dengan kajian neorosains yang menjelaskan bahwa perkembangan otak anak 0-5 tahun yang berfungsi adalah pikiran bawah sadar, yaitu meliputi perilaku, kebiasaan, kreatifitas yang berkaitan dengan pendidikan karakter, maka anak usia dini adalah usia yang tepat jika diberikan pendidikan karakter.

Pengaruh pengasuhan dan stimulus yang diberikan sejak dini juga dapat mempengaruhi karakter seseorang, hal ini berpengaruh terhadap perkembangan otak. Penelitian yang dilakukan Bruce D. Perry (ahli saraf) menjelaskan seseorang yang sering melakukan kekerasan mempunyai fungsi batang otak dan tengah otak yang dominan, Adapun fungsi otak limbic yang 
berperan mengatur emosi dan cinta juga korteks yang berfungsi mengatur daya berfikir lemah (Zubaedi, 2017:6) Untuk itu pentingnya orang tua memahami cara mendidik anak dengan baik yang disesuaikan perkembangan otak dan tumbuh kembang anak, guna meminimalisir tindakan kekerasan pada anak.

Dari berbagai hasil penelitian yang telah dijelaskan tersebut, penulis akan mengembangkan konsep mengenai urgensi pendidikan karakter untuk anak usia dini ditunjau dari kajian neurosains yang di dalamnya akan menjelaskan mengenai masa keemasan anak usia dini, konsep pendidikan karakter dan nilai-nilai yang terkandung didalamnya dan proses pembentukan karakter anak usia dini dalam kajian neurosains.

\section{METODE PENELITIAN}

Dalam penelitian ini penulis menggunakan metode penelitian kualitatif, Adapun pendekatan penelitian yang digunakan bersifat library research (penelitian kepustakaan) atau disebut juga content analysis (analisis isi). Adapun teknis pengumpulan data yang dilakukan yaitu mencatat data-data yang diambil dari berbagai sumber dari bahan-bahan tertulis kemudian mengidentifikasi bukti-bukti kontekstual yaitu dengan mencari hubungan antara data dengan realitas yang penulis teliti. Pengolahan data dalam penelitian ini bersifat kualitatif maka dilakukan dengan analisis kritis, komparasi, serta interpretasi atas berbagai hasil penelusuran dari sumber-sumber primer dan sekunder.

\section{HASIL DAN PEMBAHASAN}

\section{Anak Usia Dini dan Masa the Golden Ages}

Anak usia dini selanjutnya disebut AUD menurut National Association for the Education of Young Children (NAEYC) adalah kelompok usia yang berada pada rentang 0-8 tahun (Dadan Suryana: 1.5). Sedangkan menurut kajian yuridis di Indonesia, anak usia dini adalah rentang usia anak dari sejak lahir sampai usia enam tahun. Perbedaan usia tersebut dikarenakan usia 7 tahun di Indonesia anak-anak masuk pada rentang usia sekolah.

Dalam kajian psikologi, rentang usia anak usia dini berada pada fase Toddler, yaitu usia masa bayi-usia 3 Tahun. Fase ini merupakan fase adaptasi, dimana janin yang dalam kandungan lahir menjadi bayi. Pada fase ini mulai berfungsinya panca indera. Pertumbuhan dan perkembangan organ fisik sangat cepat. Kemelekatan orang tua terutama ibu sangat dominan karena pada fase ini masih membutuhkan Air Susu Ibu (ASI) sebagai makanan pokok. Selain itu pada usia ini anak membutuhkan seseorang (ibu) yang dapat selalu menemani dan belajar untuk mengembangkan motorik, seperti belajar, merangkak, duduk, berjalan dan bermain, selanjutnya masa anak-anak Awal (Early Childhood) Usia pada fase ini adalah 4-5 tahun 11 bulan. 
Fase ini anak masih memfokuskan diri pada orang tua dan keluarga, akan tetapi keinginan sosialisasi sudah mulai tumbuh dan pada fase ini anakanak ditandai dengan kemandi rian, kemampuan kontrol diri (self control). Meskipun masih membutuhkan keluarga, akan tetapi anak-anak membutuhkan lingkungan untuk bersosialisasi, maka pada usia ini anak sudah dapat masuk kelompok bermain. Tujuan dari kelompok bermain ini adalah agar anak dapat sosialisasi dengan teman sebayanya dan bermain dapat mengaktifkan dan bermanfaat untuk pengembangan psikomotorik dan pengembangan kepribadian anak.

Pada delapan tahun pertama mengalami pertumbuhan dan perkembnagan yang pesat, periode ini disebut the golden ages. Periode the golden ages hanya terjadi sekali dalam kehidupan manusia yaitu masa anakanak. Hal ini berdasarkan hasil penelitian di bidang neurologi yang dilakukan oleh Benyamin S. Bloom, seorang ahli pendidikan dari Universitas Chicago, Amerika Serikat mengemukakan bahwa pertumbuhan sel jaringan otak pada anak usia 0-4 tahun mencapai 50\%, hingga usia 8 tahun mencapai $80 \%$ (Direktorat Tenaga Teknis, 2003: 1).

- Pesatnya perkembangan otak tersebut bersamaan dengan pertumbuhan fisik anak. Untuk itu orang tua harus memberikan stimulasi agar anak dapat tumbuh dan berkembang dengan optimal.

Saat lahir, otak anak sudah mempunyai sel syaraf yang jumlahnya mencapai milyaran, namun jumlah itu banyak yang hilang setelah dilahirkan. Ketika otak mendapatkan suatu stimulus yang baru, maka otak akan mempelajari sesuatu yang baru. Stimulus tersebut akan menyebabkan sel syaraf membentuk sebuah koneksi baru untuk menyimpan informasi. Sel-sel yang terpakai untuk menyimpan informasi tersebut akan mengembang, juga dapat menghasilkan hormon-hormon yang diperlukan dalam perkembangan anak. sedangkan yang tidak atau jarang terstimululasi akan punah (Chamidah, 2019). Stimulasi yang terus-menerus diberikan secara rutin akan memperkuat hubungan antarsyaraf yang telah terbentuk sehingga secara otomatis fungsi otak akan menjadi semakin baik. Stimulasi yang diberikan sejak dini juga akan mempengaruhi perkembangan otak anak. Stimulasi dini yang dimulai sejak usia kehamilan 6 bulan sampai anak usia 3 tahun akan menghasilkan perubahanperubahan dalam ukuran serta fungsi kimiawi otak.

Pemberian stimulus yang baik selain akan menguatkan jaringanjaringan dan sel syaraf dalam otak, juga dapat menyimpan semua informasi yang berkaitan dengan perilaku, kecenderungan dan kebiasaan. Semua dapat terpantau dalam otak meskipun prosesnya sangat rumit. Bila dianalogikan dengan sebuah computer, otak manusia menyimpan lebih dari 100 milyar bit informasi (Lusi, 2014: 67). 
Bentuk stimulasi dapat diberikan dengan cara mudah dan sederhana. Orang tua dapat memberikan stimulus dengan kasih sayang, penghargaan, pengertian dan perhatian dengan memperhatikan fase usia anak-anak. Selain itu stimulus juga dapat dilakukan melalui pengalaman langsung dengan menggunakan panca indera, memberikan contoh yang baik kepada anak, karena anak-anak akan belajar dari apa yang dilihat dan yang didengar. Untuk itu figur orang tua menjadi teladan bagi perkembangan anak-anak dan orang tua menjadi faktor penting dalam perkembangan selain lingkunagn lainnya seperti sekolah dan teman sejawat.

\section{Nilai-nilai Pendidikan Karakter.}

Thomas Lickona sebagai peletak dasar tokoh pendidikan karakter menjelaskan tentang pendidikan karakter adalah character education is the deliberate effort to help people understand, care about, and act upon core ethical values" (pendidikan karakter adalah usaha sadar yang dilakukan untuk membantu manusia memahami, peduli tentang, dan melaksanakan nilai-nilai etika inti). Selanjutnya dalam buku Character Matters Lickona menjelaskan Character education is the deliberate effort to cultivate virtue- that is objectively good human qualities - that are good for the individual person and good for the whole society (pendidikan karakter adalah usaha sengaja (sadar) untuk mewujudkan kebajikan, yaitu kualitas kemanusiaan yang baik secara objektif, bukan hanya baik untuk individu perseorangan, tetapi juga baik untuk masyarakat secara keseluruhan) (Thomas Lickona, 2012: 15-16).

Lickona menekankan bahwa pendidikan karakter bukanlah sebuah tujuan akan tetapi sebagai sarana. Lickona mendefinisikan seseorang yang berkarakter sebagai sifat alami seseorang dalam merespons situasi secara bermoral dengan mengedepankan nilai-nilai universal seperti kejujuran, bertanggungjawab, menghargai, kerjasama.

untuk membentuk kepribadian seseorang agar tercapai kesadaran secara plural sehingga tujuan akhirnya adalah setiap orang yang memiliki karakter dapat hidup bersama dan berdampingan dan perbedaan dengan mengedepankan sikap saling kerjasama dan menghargai. Untuk itu dalam pendidikan karakter dibutuhkan kepekaan setiap orang dari berbagai disiplin ilmu untuk bersama-sama menciptakan karakter yang membumi.

Sedangkan pendidikan karakter menurut Ratna Megawangi adalah sebuah usaha untuk mendidik anak-anak agar dapat mengambil keputusan dengan bijak dan mempraktekannya dalam kehidupan sehari-hari, sehingga dapat memberikan kontribusi yang positif terhadap lingkungan (Megawangi, 2004: 95). Sedangkan pengertian pendidikan karakter menurut Helmawati adalah usaha membantu mengembangkan potensi manusia agar terbentuk akhlak, watak dan kepribadian sebagai manusia. Watak adalah sifat batin 
manusia yang mempengaruhi segenap pikiran dan tingkah laku; budi pekerti; tabiat. Akhlak adalah budi pekerti; kelakuan. kepribadian hak untuk menggunakan harkat martabat manusia (jiwa, tubuh, kehormatan) dengan leluasa (Helmawati, 2014: 157).

Senada dengan pengertian pendidikan karakter di atas, terbentuk-nya karakter seseorang menurut Bije Wijajanto yang dikutip oleh Syamsul Kurniawan, dari tindakan yang dilakukan berulang-ulang setiap hari yang tanpa disadari maupun disadari sehingga menjadi kebiasaan sebagai sebuah perilaku(Kurniawan, 2013-29).

Michele Borba mengistilahkan pendidikan karakter dengan kecerdasan moral yang diartikan sebagai kemampuan memahami yang benar dan yang salah Yaitu suatu sikap yang memiliki keyakinan etika yang kuat dan bertindak berdasarkan keyakinan tersebut sehingga dapat bersikap benar dan terhormat. Definisi tersebut di atas seperti yang diungkapkan Albertus yang menjelaskan bahwa pendidikan karakter adalah diberikannya tempat bagi kebebasan individu dalam menghayati nilai-nilai yang dianggap sebagai baik, luhur dan layak diperjuangkan sebagai pedoman tingkah laku bagi kehidupan pribadi berhadapan dengan dirinya, sesama dan Tuhan (Koesoema, 2010: 5).

Pendidikan karakter dilakukan dengan contoh atau perlakuan bukan hanya sebatas teori (Tafsir, 2011: 4). Untuk itu penting kiranya diberikan pemahaman dan pengetahuan yang baik dari pendidik dan orang tua yang dapat dilaksanakan dalam kehidupan sehari-hari, untuk itu dalam pendidikan karakter harus dibangun berdasarkan tiga komponen yaitu pengetahuan, sikap dan perilaku. Ketiga komponen ini tidak dapat dipisahkan karena masingmasing memiliki keterikatan. Ketiga komponen tersebut menjadi barometer bagi terlaksananya Pendidikan karakter. Untuk itu setiap orang tua dan pendidik harus selalu berupaya untuk menanamkan karakter positif kepada setiap anak, sebagai bentuk sumbangsih dan tauladan baik melalui lisan, sikap dan praktek.

Pendidikan karakter yang diberikan kepada anak sedini mungkin bahkan semenjak dalam kandungan akan memudahkan orang tua dalam mengarahkan dan mendidik karakter anak-anak, karena salah satu hal yang menyebabkan karakter sulit diterapkan dan anak cenderung susah diatur karena pola asuh anak yang tidak tuntas dan tidak sesuai tahapan usia.

Dari berbagai definisi mengenai pendidikan karakter di atas penulis dapat mendefinisikan pendidikan karakter sebagai upaya yang dilakukan untuk menanamkan kecerdasan dalam berfikir, penghayatan dalam bentuk sikap, dan pengalaman dalam bentuk perilaku yang sesuai dengan nilai-nilai luhur yaitu nilai agama dan budaya yang dijalankan dalam kehidupan sehari-hari baik yang berhubungan dengan Maha Pencipta, berhubungan dengan manusia dan 
berhubungan dengan alam raya, sehingga memampukan manusia menjadi pemelihara alam raya yang dapat hidup saling menghargai dan melengkapi.

Pendidikan karakter merupakan satu bagian sikap yang bekerja secara integral, dimana sikap yang satu dengan sikap yang lain harus saling berkaitan. Sebagai contoh setiap perilaku memiliki konsekuensi, baik itu positif maupun negatif, hasil dari perilaku tersebut merupakan berkaitan dengan apa yang diungkapkan bagaimana sikap dan bagaimana tindakan dari perbuatan tersebut. Untuk itu perlu adanya nilai-nilai yang menjadi acuan sebagai bahan pelaksanaan pendidikan karakter.

Nilai-nilai yang terkandung dalam pendidikan karakter ini merupakan bagian kebaikan yang dapat diterima oleh siapa saja sebagai panduan dan acuan dalam pembentukan karakter. Selain itu pembentukan karakter ini bersifat menyeluruh untuk kalangan dan rentang usia mana saja.

Untuk menciptakan Pendidikan karakter ini setiap orang dan kelompok/ lembaga memberikan sumbangsih pemikiran dan praktis. Dimana anggota parlemen (DPR) berupaya memasukkan pendidikan karakter ini sebagai kurikulum yang sekarang sudah disosialisasikan menjadi Kurikulum Tiga Belas. Lembaga sekolah dan dewan guru berupaya menanamkan pendidikan karakter melalui berbagai pendekatan yang dilakukan dalam pengajaran. Beberapa negara berupaya untuk memperkecil jumah murid dalam kelas dan meningkatkan standar akademis. Para psikolog mencoba mengembangkan teori-teori baru yang lebih lengkap seperti Daniel Goleman dengan teori kecerdasan emosi, Howard Gardner memberikan pemahaman tentang kecerdasan anak melalui kecerdasan majemuk. Upaya ini dilakukan merupakan bentuk tanggung jawab dan sumbangsih yang diberikan untuk perbaikan karakter.

Dalam Pasal 3 Undang-undang Sistem Pendidikan Nasional Nomor 20 tahun 2003 dijelaskan bahwa pendidikan nasional berfungsi mengembangkan dan membentuk watak serta peradaban bangsa yang bermartabat dalam rangka mencerdaskan kehidupan bangsa, bertujuan untuk berkembangnya potensi peserta didik agar menjadi manusia beriman dan bertaqwa kepada Tuhan Yang Maha Esa, berakhlak mulia, sehat, berilmu, cakap, kreatif, mandiri dan menjadi warga negara yang demokratisdan bertanggung jawab.

Sebagai manivestasi pelaksanaan Undang-undang Sistem Pendidikan Nasional tersebut, Departemen Pendidikan Nasional mengembangkan 18 nilai-nilai pengembangan pendidikan budaya dan karakter. 18 nilai-nilai dalam pendidikan karakter tersebut yaitu religius, jujur, toleransi, disiplin, kerja keras, kreatif, mandiri, demokratis, rasa ingin tahu, semangat kebangsaan, cinta tanah air, menghargai prestasi, bersahabat/komunikatif, cinta damai, gemar membaca, peduli lingkungan, peduli sosial dan tanggung jawab. Nilai-nilai tersebut sudah mulai dilaksanakan sejak tahun ajaran 2001 seluruh tingkat 
pendidikan di Indonesia yaitu dengan memasukkan pendidikan karakter ke dalam materi pelajaran.

Menurut Khan nilai-nilai yang terkandung pendidikan karakter adalah nilai religius, nasionalis, cerdas, tanggung jawab, disiplin, mandiri, jujur, arif, hormat, santun, dermawan, suka menolong, gotong royong, percaya diri kerja keras, tangguh, kreatif, kepemimpinan, demokratis, rendah hati toleransi, solidaritas dan peduli (Khan, 2010: 34).

Nilai pendidikan karakter tersebut merupakan nilai dasar yang menjadi pola asuh yang semestinya dilaksanakan dari awal perkembangan kehidupan. Thomas Lickona memberikan nilai-nilai pendidikan karakter tersebut berdasarkan nilai-nilai luhur yang selama ini selalu diterapkan yaitu kecintaan akan Tuhan dan makhluk-Nya, kemandirian dan tanggung jawab, kejujuran, hormat dan santun, dermawan, percaya diri, adil, rendah hati dan memiliki jiwa damai dan toleransi (Lickona, 1992: 12-22).

Michele Barba dalam buku Membangun Kecerdasan Moral (Barba, 2008: 7-8). Dalam buku tersebut dijelaskan pendidikan karakter atau kecerdasan moral harus memiliki nilai-nilai sebagai rujukan. Pertama nilai empati. Ini merupakan nilai dasar bagi perkembangan karakter anak untuk dapat memahami perasaan orang lain. Empati dapat menanamkan rasa peka terhadap kebutuhan sehingga mampu memberikan dan merasakan apa yang dirasakan orang lain sehingga terhindar untuk melukai orang lain baik dengan perasaan, berbicara maupun tindakan. Kedua nilai hati nurani. Nilai ini menjadi penting karena menjadi fondasi seseorang untuk berbuat jujur, bertanggung jawab dan memiliki integritas tinggi. Dengan hati nurani yang dimiliki seseorang akan selalu cenderung untuk melakukan hal-hal positif dan membentengi dari perbuatan tidak baik. Karena dengan hati nurani tersebut seseorang akan gelisah ketika melakukan perbuatan buruk. Ketiga nilai kontrol diri. Nilai ini akan menahan dorongan dalam diri seseorang untuk berfikir sebelum bertindak sehingga kemungkinan melakukan perbuatan tidak baik akan sedikit. Selain itu kontrol diri akan menanamkan sifat mandiri dalam diri seseorang, karena dengan kontrol diri seseorang harus bertanggung jawab untuk mengendalikan tindakan dan berupaya untuk melakukan tindakan yang baik. Keempat nilai rasa hormat. Penanaman rasa hormat yang diterapkan sejak dini akan menjadikan seseorang menghargai orang lain dan menghargai perbuatan orang lain serta akan memperlakukan orang lain sebagaimana memperlakukan diri sendiri sehingga meminimalisir rasa permusuhan, ketidakadilan, dan bertindak kasar. Kelima nilai kebaikan hati. Nilai ini akan menunjukkan kepedulian terhadap kesejahteraan dan perasan orang lain. Menimbulkan rasa kasih sayang dan tidak selalu memikirkan diri sendiri dan membangun sikap kebersamaan dan gotong royong. Keenam nilai toleransi. Nilai ini akan membentuk seseorang untuk menghargai orang lain, baik karena 
perbedaan gender, suku bangsa, bahasa, agama, kemampuan. Sikap ini akan memperlakukan orang lain, baik menghargai dan pengertian, sehingga terhindar dari sikap permusuhan, fanatisme berlebihan dan anarkis. Ketujuh nilai keadilan. Sikap ini akan mendorong seseorang untuk berlaku adil, membela memperlakukan pihak yang diperlakukan secara tidak adil dan memperlakukan orang lain setara tanpa melihat perbedaan suku, bahasa, budaya, gender dan agama.

Jika diamati berdasarkan nilai-nilai pendidikan karakter tersebut di atas, berbagai pandangan tokoh memberikan pandangan yang sama terhadap nilainilai pendidikan karakter. Nilai-nilai pendidikan karakter akan dapat tertanam dan diaplikasikan dalam kehidupan bermasyarakat jika seluruh komponen lembaga dan masyarakat berupaya untuk menjadikan pendidikan karakter sebagai sentral dalam mendidik anak-anak. Ibnu Miskawaih menjelaskan bahwa pendidikan karakter akan tertanam jika sikap yang terdapat dalam nilai pendidikan tersebut tertanam kuat menjadi kepribadian (Miskawaih, 1934: 40), hal ini tentu saja memerlukan waktu dan pembiasaan yang kontinu, hal lain untuk menciptakan nilai-nilai tersebut adalah menjadi perilaku pembiasaan sehingga dengan mudah dan tanpa pertimbangan seseorang berkarakter dengan baik, dan yang paling penting dari upaya penanaman pendidikan karakter adalah setiap perilaku dan nilai-nilai yang dilaksanakan tanpa paksaan dan dengan kesadaran sendiri melakukan hal tersebut. Selanjutnya adalah nialinilai yang dilaksanakan dalam kehidupan tersebut tidak dibuat-buat atau perilaku tersebut apa adanya, sebagaimana pengertian moral atau akhlak yang menjelaskan bahwa perilaku yang spontan tanpa rekayasa. Yang tidak kalah penting dalam penanaman karakter (akhlak) menurut Ibnu Miskawaih adalah adanya motivasi keimanan yang kuat bahwa setiap perilaku diyakini akan dipertanggung jawabkan dan disaksikan Allah SWT.

Berbagai nilai-nilai karakter yang digambarkan di atas, mengisyaratkan bahwa penanaman karakter setiap manusia akan lebih mudah jika dilaksanakan semenjak usia dini melalui pendekatan pembiasaan dan keteladanan oleh orang tua, pendidik maupun pengasuh, melalui perkataan, sikap dan perbuatan. Dilakukan secara terus menerus dan disesuaikan dengan usia tumbuh kembang dan perkembangan otak anak.

\section{Proses Pembentukan Karakter Pada Anak Usia Dini}

Makna karakter jika dilihat dari makna asal adalah charasaen berasal dari bahasa Yunani yang artinya "mengukir". Sifat yang terdapat dalam karakter (ukiran) adalah mengukir. Karakter merupakan sifat yang ada dalam diri. Munir menjelaskan karakter sebagai sebuah pola, yang berupa pikiran, sikap maupun tindakan yang melekat pada seseorang yang sulit dihilangkan karena terbentuk sangat kuat. Pengertian karakter tersebut menjelaskan bahwa 
sifat dari karakter adalah melekat dan sulit untuk dihilangkan. Faktor penentu terbentuknya karakter adalah pikiran.

Pikiran merupakan program yang terbentuk dari berbagai pengalaman kehidupan setiap manusia. Fungsi dari pikiran adalah membentuk kepercayaan yang dapat membentuk perilaku seseorang. Secara fitrah manusia, jika pikiran (program) tersebut selaras dengan kebaikan alam (universal) maka akan memberikan ketenangan.

Terdapat tiga bagian tentang pikiran yang dapat dipelajari, pertama pikiran sadar (conscious mind), kedua pikiran kritis (critical factor), ketiga. pikiran bawah sadar (subconscious mind). Pikiran sadar (conscious mind) merupakan lapisan pikiran terluar, yang berfungsi menerima informasi yang diberikan oleh panca indra manusia seperti, menerima informasi tentang mengamati warna, merasakan tekstur sebuah benda, mendengar suara, dan lainnya yang melibatkan panca indra manusia. Sifat pikiran sadar ini adalah menampung memori jangka pendek. Pikiran kritis berfungsi melindungi pikiran bawah sadar dari informasi-informasi yang merugikan dan mengancam keselamatan manusia. Karena sifat pikiran kritis ini menganalisa dan membanding-bandingkan informasi yang diterima oleh pikiran sadar. Pikiran kritis merupakan bagian yang penting. Ketiga pikiran bawah sadar adalah tempat yang paling dominan untuk mempengaruhi perilaku manusia, dan menurut pakar, perilaku manusia 88\% dipengaruhi oleh pikiran bawah sadar. Karena dalam pikiran bawah sadar menyimpan beberapa faktor kunci terhadap perilaku manusia seperti persepsi, emosi, kebiasaan, intuisi, memory jangka panjang, kreativitas, belief and value, dan self image. Pikiran sadar dan bawah sadar sangat mempengaruhi kehidupan, bawah sadar mempengaruhi $88 \%$ sedangkan pikiran sadar mempengaruhi sekitar $12 \%$ dalam kehidupan (Anonymous, 2015: 46-47). Pikiran sadar dikendalikan oleh akal, ingatan dan waktu. Pikiran sadar juga terbentuk karena aktifnya panca indera (Gunawan, 2012: 23). Fungsi dari pikiran sadar adalah mengidentifikasi informasi, membandingkan, menganalisa dan memutuskan. Sedangkan pikiran bawah sadar memiliki fungsi menyimpan, kebiasaan, emosi, memori jangka panjang, intuisi, kepribadian, kreatifitas, keyakinan, persepsi dan nilai. Pikiran sadar secara fisik terletak di bagian korteks otak bersifat logis dan analisis, sedangkan pikiran bawah sadar berada di medulla oblongata yang sudah terbentuk sejak dalam kandungan (Madjid, 2017: 17). Fakta secara fisik pikiran bawah sadar ini dapat dibuktikan ketika bayi menangis yang bisa tenang dalam dekapan ibunya, karena semenjak dalam kandungan bayi sudah mengenal sosok ibunya melalui rahim dan detak jantung.

Jika dilihat dari fugsinya, pikiran bawah sadar berfungsi untuk membentuk karakter. Fungsi didalamnya terdapat kepribadian. Sedangkan terbentuknya pikiran bawah sadar terbentuk dan terbuka sejak dalam 
kandungan sampai usia lima tahun. Selama rentang usia ini kemampuan nalar seseorang belum tumbuh, sehingga sangat memungkinkan untuk menanamkan pendidikan dengan pembentukan karakter. Jika distimulus dengan baik pada rentang usia ini akan menyimpan memori jangka panjang yang dapat membentuk karakter seseorang.

Rentang usia balita ini pembentukan karakter sangat berpengaruh. Usia 0-4 tahun perkembangan kognitif mencapai 50\%, usia ini disebut masa the golden ages. Usia 4-8 tahun sebesar 30\% dan usia 9-17 tahun 20\%. Apa yang dilihat, didengar dan dipelajari akan mengakar dan membentuk persepsi anak tentang kehidupan yang dialami. Jika anak pada usia ini dibesarkan dengan kasih sayang, penghargaan dan empati, maka apa yang dialami tersebut akan terukir dan mengakar menjadi karakter. Akan tetapi jika apa yang dilihat, dialami dan dirasakan sesuatu yang menyakitkan dan tidak aman, maka akan membentuk karakter yang mudah putus asa, labil dan keras kepala. Untuk itu peran orang terdekat yaitu orang tua memberikan andil dalam membentuk kepribadian anak.

Lingkungan keluarga (orang tua) menjadi faktor pembentuk pendidikan karakter. Kepercayaan (believe) orang tua akan sesuatu yang diyakini mengenai kebenaran dan kesalahan merupakan faktor pembentuk karakter anak. Jika orang tua meyakini akan sesuatu hal yang dianggap benar, maka hal tersebut akan diturunkan kepada anak.

Believe (kepercayaan) terbentuk bukan terkait persoalan agama atau keyakinan seseorang. Akan tetapi terbentuk karena pengalaman yang berulangulang atau pengalaman yang berkesan (Wibowo, 2018: 171). Untuk itu penting kiranya bagi orang tua sebagai pendidik pertama menanamkan kepercayaan positif kepada anak-anak agar tumbuh menjadi pribadi positif dan kuat. Lingkungan selanjutnya yang berpengaruh dalam pembentukan karakter adalah lingkungan sekitar, seperti sekolah, lingkungan bermain, keluarga besar, televisi, buku, dan internet. Informasi yang didapatkan dari lingkungan kedua ini akan memfungsikan pikiran sadar menganalisa dan menalar. Sehingga semakin menguatkan karakter dalam diri seseorang.

al-Ghazali menjelaskan bahwa pembinaan dan pengajaran anak diawali dengan memberikan pendidikan akhlak yang baik, dan menjaganya dari pergaulan yang buruk merupakan cara untuk memberikan kehidupan yang hakiki bagi sang anak, ini dilakukan diawal awal pertumbuhan anak. Jika anak di biarkan tumbuh begitu saja, ia akan tumbuh dengan akhlak yang buruk, berbohong, mendengki, mencuri dan sifat-sifat buruk lainya. Menjaga anak dari semua perilaku tersebut adalah bagian dari pembinaanya (Ghazali, 2011: 296).

Jika merujuk pada penjelasan mengenai tumbuh kembang anak yang telah dipaparkan tersebut, setiap fase perkembangan anak menjadi penting untuk diketahui orang tua dan pendidik. Urgensi tumbuh kembang anak 
menjadi bagian yang tidak dapat dipisahkan. Untuk itu pola asuh dan pola ajar bagi anak harus dilakukan pada setiap fase perkembangan anak agar anak dapat tumbuh dan berkembang sesuai tahapan usia dan dapat membangun karakter anak sejak dini dan akan dikembangkan sampai masa dewasa.

\section{KESIMPULAN}

Dalam kajian neurosains, fase anak usia dini memiliki tahapan yang penting atau disebut the golden ages. Pada tahap ini perkembangan otak anak usia 0-5 tahun yang berfungsi adalah pikiran bawah sadar sebanyak $88 \%$. Pikiran bawah sadar meliputi perilaku, kebiasaan, kreatifitas. Hal ini berkaitan erat dengan pendidikan karakter. Jika dilihat dari fugsinya, pikiran bawah sadar berfungsi untuk membentuk karakter. Fungsi didalamnya terdapat kepribadian. Sedangkan terbentuknya pikiran bawah sadar terbentuk dan terbuka sejak dalam kandungan sampai usia lima tahun. Selama rentang usia ini kemampuan nalar seseorang belum tumbuh, sehingga sangat memungkinkan untuk menanamkan pendidikan dengan pembentukan karakter. Jika distimulus dengan baik pada rentang usia ini akan menyimpan memori jangka panjang yang dapat membentuk karakter seseorang.

\section{REFERENSI}

Barba, Michelle 2008. Membangun Kecerdasan Moral, Jakarta: Gramedia Pustaka Utama.

Chamidah, Atien Nur. Pentingnya stimulasi Dini Bagi Tumbuh Kembang Otak Anak, http://staffnew.uny.ac.id/upload/132326899/pengabdian/pentingny a-stimulasi-dini-bagi-tumbuh-kembang-otak-anak.pdf.

Dadan Suryana, Modul 1: Hakikat Anak Usia Dini.

Direktorat Tenaga Teknis. 2003. Pertumbuhan dan Perkembangan Anak Usia Dini, 0 - 6 Tahun, Jakarta: PT Grasindo.

al Ghazali, Abu Hamid Muhammad bin Muhammad 2011, Ihya' Ulum alDin, Surabaya: PT Elba Fitrah Mandiri Sejahtera.

Helmawati, 2014. Pendidikan Keluarga, Bandung: Remajarosdakarya.

Khan, Yahya, 2010, Pendidikan Karakter Berbasis Potensi Diri, Yogyakarta.: Pelangi Publishing. 
Kurniawan, Syamsul 2013. Pendidikan Karakter: Konsepsi dan

Implementasinya Secara Terpadu di Lingkungan Keluarga, Sekolah, Perguruan Tinggi dan Masyarakat, Yogyakarta: Ar-Ruzz Media.

Koesoema, Doni 2010. Pendidikan Karakter Strategi Mendidik Anak di Zaman Global, Jakarta: PT. Grasindo.

Lickona, Thomas, 2012. Educatin for Character: How Our School Can Teach Respect and Responsibility, New York: Bantam Books. 2012. Persoalan Character, diterjemahkan oleh Juma Abdu Wamaungo dan Jean Antunes Rudolf Zien dari judul Character Matters. Jakarta Bumi Aksara.

Lusi, Semuel S. 2014. SEIP Intelligence: Spiritual, Emotional, Intellectual dan Physique, Yogyakarta: Kanisius.

Madjid, Abdul dan Dian Andayani, 2017. Pendidikan Karakter Perspektif Islam, Bandung: Remaja Rosdakarya.

Miskawaih, Ibn 1934. Tahzib al-Akhlaq wa Tathhir al-'Araq, Mesir: alMathba'ah al-Misriyat.

Nukman, Ilhamuddin 2009. Mind Revolution, Yogyakarta: Diva Press.

Ratna Megawangi, 2004. Pendidikan Karakter: Solusi yang Tepat untuk Membangun Bangsa, Bogor: Indonesia Heritage Foundation.

Slavin, Robert E. 2017. Psikologi Pendidikan, Penerjemah Marianto Samosir dengan judul buku Educational Psychology: Theory and Practice, Jakarta: Indeks.

Subiyono dkk, 2012. Hipnometafisika, Yogyakarta: Deepublish.

Wibowo, Timothy 2018.Success Begins with Character, Surabaya: Pendidikan Karakter.

Tafsir, Ahmad, 2011, Pendidikan Karakter Perspektif Islam, Jakarta: Remaja Rosda Karya. 
Aas Siti Sholichah

Zubaedi, 2017. Strategi Taktis Pendidikan Karakter (untuk PAUD dan Sekolah), Depok: PT. RajaGrafindo Persada.

JECIES: Journal of Early Childhood Islamic Education Study Vol. 01, Nomor 01, Januari - Juni 2020 